\title{
DIRASAH
}

Volume 2, Number 2, Agustus 2019

p-ISSN: 2615-0212 | e-ISSN: 2621-2838

https://ejournal.iaifa.ac.id/index.php/dirasah

\begin{tabular}{|c|c|c|}
\hline Accepted: & Revised: & Published: \\
Juni 2019 & Juli 2019 & Agustus 2019 \\
\hline
\end{tabular}

\section{Pembelajaran Bahasa Kedua yang Menyenangkan Menggunakan Metode Bermain Peran pada Siswa}

\author{
Mahfud Nahrowi \\ Intitut Agama Islam Negeri Salatiga, Indonesia \\ e-mail:mahfud.nahrowikds@gmail.com \\ Moh.Badiul Anis \\ Intitut Agama Islam Negeri Salatiga, Indonesia \\ e-mail: ambadiul@gmail.com
}

\begin{abstract}
This research aims to describe the learning of second language that is pleasing physically and nonphysically after using the role playing method in class II A MI NU Miftahul Huda 02 Karangmalang. The research method used in this study is descriptive, this form of research is a survey, the nature of this research is qualitative and this type of research is the Research Action Class (PTK) which in its implementation collaborate With class teachers. The subjects in this study were 1 grade teacher and 18 grade II students A. Pleasant Second Language learning using a role-playing method in class II A MI NU Miftahul Huda 02 Karangmalang increased from base line by $19.59 \%$ to The II cycle became $76.95 \%$ increased by $57.36 \%$ with the "high enough".
\end{abstract}

Keywords: Second Language Learning, fun, role-playing methods 


\section{Pendahuluan}

Bahasa merupakan alat komunikasi yang paling esensial bagi manusia. Bahasa yang dimiliki oleh manusia sangat dinamis sehingga terus berkembang dari waktu ke waktu. Dalam kehidupan sehari-hari, manusia menggunakan bahasa sebagai sarana untuk mengungkapkan pikiran, bersosialisasi, dan memenuhi hasrat hidupnya. Oleh karena itu, dapat dikatakan bahwa berbahasa adalah kebutuhan dasar setiap manusia.

Berdasarkan definisi di atas, kemampuan berbahasa yang baik tentunya menjadi tuntutan bagi setiap individu yang ingin berkomunikasi. Agar dapat berkomunikasi dengan baik maka setiap individu harus menguasai bahasa yang digunakan dalam masyarakat tersebut.

Bahasapun dianggap sebagai sesuatu yang istimewa, sebab bahasa merupakan sarana manusia untuk berpikir yang merupakan sumber awal manusia memperoleh pemahaman dan ilmu pengetahuan. Sebagai simbol sebuah pemahaman, bahasa telah memungkinkan manusia untuk memahami apa yang ada di sekitarnya, dan mengantarkan dia memiliki ilmu pengetahuan dan keahlian.

Dari berpikir itulah kemudian manusia mencoba mencari dan meneliti dari mana bahasa berasal, sejak kapan manusia berbahasa, dan dari mana manusia memperoleh serta mempelajarinya. Bahasa tidak serta merta dipahami dan dikuasai oleh anak manusia yang baru lahir. Memerlukan berbagai tahapan untuk dapat berbahasa secara fasih dan lancar serta dapat dipahami dan memahami apa yang orang lain sampaikan.

Tulisan ini mengemukakan tentang observasi terhadap Peningkatan hasil pembelajaran bahasa kedua yang menyenangkan menggunakan metode berman peran pada siswa kelas II A MI NU Miftahul Huda 02 Karangmalang.

\section{Kajian Pustaka}

\section{Pembelajaran yang Menyenangkan}

Pembelajaran yang menyenangkan merupakan sebuah proses pembelajaran yang di dalamnya terdapat kohesi yang kuat antara pendidik dan peserta didik dengan tanpa ada perasaan tertekan. ${ }^{1}$ Dengan kata lain, pembelajaran yang menyenangkan adalah adanya pola hubungan yang baik antara guru dan siswa dalam proses pembelajaran. Guru memposisikan diri sebagai mitra belajar siswa

1 E. Mulyasa, Kurikulum yang di Sempurnakan (Bandung: PT Remaja Rosdakarya, 2006), 194.

Dirasah, Vol. 2, No. 2, Agustus 2019 
di kelas, sehingga tidak ada beban bagi siswa dalam melakukan proses pembelajaran. Untuk mewujudkan pembelajaran yang menyenangkan ini, guru dituntut untuk mampu mendesain materi pembelajaran dengan baik serta mengkombinasikannya dengan strategi pembelajaran yang mengedepankan keterlibatan aktif siswa di kelas, seperti; simulasi, game, team quiz, bermain peran, dan sebagainya.

Pembelajaran menyenangkan telah menjadi kecenderungan dan kebutuhan pembelajaran saat ini dan terlebih lagi untuk waktu yang akan datang. Melalui pembelajaran menyenangkan diharapkan kualitas proses dan hasil belajar siswa menjadi lebih berkualitas dan optimal. Dalam pelaksanaannya, pembelajaran yang menyenangkan memerlukan kehadiran beragam variasi metode. Berdasarkan refleksi guru selama ini guru tidak menganggap pentingnya pembelajaran yang menyenangkan. Guru tidak memperhatikan secara cermat tentang pembelajaran yang menyenangkan, baik secara fisik maupun secara non fisik.

Berdasarkan pengamatan awal yang dilakukan saat pembelajaran Bahasa Indonesia (sebagai bahasa kedua) diperoleh informasi sebagai berikut: (1) menyenangkan secara fisik adalah $21,11 \%$, (2) menyenangkan secara non fisik $18,06 \%$. Berdasarkan uraian tersebut disimpulkan terjadi kesenjangan antara harapan dengan kenyataan yang ada. Untuk mengatasi kesenjangan tersebut digunakan metode bermain peran. Melalui metode bermain peran siswa diajak untuk belajar memecahkan masalah pribadi, dengan bantuan kelompok sosial yang anggotanya teman-temannya sendiri. Dengan kata lain metode ini berupaya membantu individu melalui proses kelompok sosial. Melalui bermain peran, para siswa mencoba mengeksploitasi masalah-masalah hubungan antar manusia dengan cara memperagakannya. Hasilnya didiskusikan dalam kelas. Proses belajar dengan menggunakan metode bermain peran diharapkan siswa mampu menghayati tokoh yang dikehendaki, keberhasilan siswa dalam menghayati peran itu akan menentukan apakah proses pemahaman, penghargaan dan identifikasi diri terhadap nilai berkembang.

Sumardi mengemukakan bahwa menyenangkan merupakan ciri ke empat dari PAIKEM (Pembelajaran aktif, Inovatif, kreatif dan menyenangkan) dengan maksud pembelajaran dirancang untuk menciptakan suasana yang menyenangkan. Menyenangkan berarti tidak membelenggu, sehingga siswa memusatkan perhatiannya secara penuh pada pembelajaran, dengan demikian 
waktu untuk mencurahkan perhatian (time of task) siswa menjadi tinggi. Dengan demikian diharapkan siswa dapat meningkatkan hasil belajarnya. ${ }^{2}$

Meir memberikan pengertian menyenangkan atau fun sebagai suasana belajar dalam keadaan gembira. Susana gembira disini bukan berarti suasana ribut, hura-hura, kesenangan yang sembrono dan kemeriahan yang dangkal. ${ }^{3}$ Indrawati dan Setiawan mengemukakan bahwa ciri-ciri pembelajaran yang menyenangkan dan tidak menyenangkan adalah sebagai berikut. Ciri suasana yang menyenangkan adalah; rileks, bebas dari tekanan, aman, menarik, bangkitnya minat belajar, adanya keterlibatan penuh, Perhatian peserta didik tercurah h. Lingkungan belajar yang menarik, bersemangat, perasaan gembira, konsentrasi tinggi. ${ }^{4}$

Sementara sebaliknya pembelajaran menjadi tidak menyenangkan apabila; Tertekan, perasaan terancam, perasaan menakutkan, perasa tidak berdaya, tidak bersemangat, malas/tidak berminat, jenuh/bosan, suasana pembelajaran monoton, pembelajaran tidak menarik siswa

Maka pembelajaran yang menyenangkan adalah pendekatan yang digunakan oleh pengajar dalam hal ini adalah guru untuk membuat siswa lebih dapat menerima materi yang disampaikan yang dikarenakan suasana yang menyenangkan dan tanpa ketegangan dalam menciptakan rasa senang. Penciptaan rasa senang berkait dengan kondisi jiwa bukanlah proses pembelajaran tersebut menciptakan suasana ribut dan hura-hura. Dan menyenangkan atau mengasyikkan dalam belajar dikelas bukan berarti menciptakan suasana huru-hara dalam belajar di kelas namun kegembiraan disini berarti bangkitkan minat, adanya keterlibatan penuh serta terciptanya makna, pemahaman (penguasaan atas materi yang dipelajari) dan nilai yang membahagiakan siswa.

Aspek yang ingin ditingkatkan pada penelitian ini adalah menyenangkan secara fisik dan non fisik. Dari kedua aspek tersebut dapat ditarik indikator kinerja sebagai berikut:

${ }^{2}$ Kamin Sumardi, Pembelajaran Dengan Pendekatan Pakem (Cirebon: Disampaikan Dalam Seminar Nasional Creating Engaging Lesson, 2010).

${ }^{3}$ Dave Meir, The Accelerated Learning Handbook. Terjemahan oleh Rahmani Astuti (Bandung: Kaifa, 2002), 36.

4 W. Setiawan, Pembelajaran Aktif, Kreatif, Efektif, dan Menyenangkan untuk Guru SD (Bandung: PPPPTK IPA, 2009), 16.

Dirasah, Vol. 2, No. 2, Agustus 2019 
1. Menyenangkan secara fisik: bergembira, senyum, berani menunjukkan tangan saat bertanya, tertawa dan tepuk tangan

2. Menyenangkan secara non fisik: perhatian tercurah, bersemangat, tertarik dan timbulnya minat dalam pembelajaran

Pembelajaran yang menyenangkan dapat diciptakan melalui penerapan berbagai strategi pembelajaran. Setiap siswa dapat menikmati proses pembelajaran yang menyenangkan jika lingkungan fisiknya kondusif untuk belajar. Menjadikan pembelajaran yang menyenangkan, akan menjadikan siswa suka dan senang menerima pelajaran yang disampaikan. Ada beberapa aspek menyenangkan dalam pembelajaran: bermain, merangsang dengan hal-hal yang menarik/disukai, penuh pujian dan suasana kelas

\section{Metode Bermain Peran}

Metode bermain peran adalah salah satu proses pembelajaran yang tergolong dalam simulasi. Menurut Diane mengemukakan bahwa metode simulasi adalah suatu cara pengajaran dengan melakukan proses tingkah laku secara tiruan. ${ }^{5}$

Permainan merupakan pengalaman belajar yang menyenangkan bagi anak. Bermain dilakukan sukarela dan tidak ada paksaan atau tekanan dari luar atau kewajiban. Dworetzky dalam Endang Komara memberikan batasan, bahwa setidaknya ada lima kriteria dalam bermain peran, yaitu : (1) motivasi intrinsik, artinya kegiatan bermain dimotivasi dari dalam diri anak, bukan karena adanya tuntutan atau paksaan, (2) pengaruh positif, artinya kegiatan bermain merupakan tingkah laku yang menyenangkan atau menggembirakan, (3) bukan dikerjakan sambil lalu, bermain bagi anak merupakan kegiatan yang utama dan lebih bersifat pura-pura, (4) cara/tujuan, cara bermain lebih diutamakan daripada tujuannya, (5) kelenturan, kelenturan ditunjukkan baik dalam bentuk maupun dalam hubungan serta berlaku dalam setiap situasi. ${ }^{6}$

Kriteria permainan dapat diamati berdasarkan tiga tahap permainan Piaget yaitu fungsional, simbolik, dan permainan yang mempunyai aturan yang berevolusi pada anak-anak. Konsep ini berguna bagi para guru karena mereka

\footnotetext{
${ }^{5}$ Novita Diane, Mengajar Lewat Permainan (Jakarta: PT Gramedia Widiasarana Indonesia, 2005), 83

${ }^{6}$ Endang Komara, Model Bermain Peran dalam Pembelajaran Partisipatif (TP: FKIP UNTAN Pontianak, 2009), th.
} 
mungkin mempunyai definisi permainan mereka sendiri yang berkaitan dengan konteks pekerjaan mereka. Mengkonseptualkan permainan dan pekerjaan sebagai rangkaian juga mengakui fakta bahwa kegiatan yang menyerupai kerja atau setidak-tidaknya juga dapat mempromosikan pembelajaran anak-anak dengan efektif, terutama jika mengandung ciri seperti motivasi intrinsik, perhatian, dan keterlibatan aktif.

Keterlibatan aktif dalam belajar merupakan suatu kegiatan yang dilakukan untuk menghasilkan perubahan pengetahuan-pengetahuan, nilai-nilai sikap, dan keterampilan pada siswa sebagai latihan yang dilaksanakan secara sengaja. Dalam setiap pembelajaran aktivitas fisik, mental dan emosional sangat diperlukan. Begitu juga halnya dalam metode bermain peran. Karena dalam pembelajaran ini menuntut siswa dalam membaca skenario pembelajaran, menyimak penjelasan guru tentang langkah-langkah bermain peran, menulis materi pembelajaran, berdiskusi baik dengan teman kelompoknya maupun secara klasikal.

Selain itu juga dalam pembelajaran metode bermain peran siswa diberikan kesempatan menyimpulkan materi pembelajaran, mengklarifikasi pertanyaan baik dari guru maupun dari teman yang lain, diberikan kesempatan dan kebebasan bertanya dan menjawab pertanyaan sehingga siswa merasa sangat dihargai dan akan terfokus dan bersungguh-sungguh dalam mengikuti pembelajaran yang dilakukan. Dengan metode bermain peran maka pembelajaran akan terlihat jelas dan memungkinkan akan terjadi peningkatan yang optimal.

Metode bermain peran (role playing) mempunyai beberapa kelebihan metode ini menurut Sagala yaitu: siswa melatih dirinya untuk melatih memahami dan mengingat isi bahan yang akan diperankan, siswa akan terlatih untuk berinisiatif dan berkreatif, bakat yang terdapat pada siswa dapat dipupuk sehingga dimungkinkan akan muncul atau tumbuh bibit seni peran di sekolah, kerja sama antar pemain dapat ditumbuhkan dan dibina dengan sebaik-baiknya, siswa memperoleh kebiasaan untuk menerima dan membagi tanggung jawab dengan sesamanya dan bahasa lisan siswa dibina dengan baik agar mudah dipahami orang.

Sedangkan kekurangan metode bermain peran (role playing), yaitu: metode bermain peranan memerlukan waktu yang relatif panjang/banyak, memerlukan kreativitas dan daya kreasi yang tinggi dari pihak guru maupun murid dan ini tidak semua guru memilikinya, kebanyakan siswa yang ditunjuk sebagai pemeran 
merasa malu untuk memerlukan suatu adegan tertentu, apabila pelaksanaan sosiodrama dan bermain pemeran mengalami kegagalan, bukan saja dapat memberi kesan kurang baik, tetapi sekaligus berarti tujuan pengajaran tidak tercapai, tidak semua materi pelajaran dapat disajikan melalui metode ini, sebagian besar anak yang tidak ikut drama mereka menjadi kurang aktif, kelas lain sering terganggu oleh suara pemain dan penonton yang kadang-kadang bertepuk tangan.

Menurut Sagala ada beberapa cara untuk mengatasi kekurangan pada metode pembelajaran bermain peran (role playing) ini diantaranya: (1) Guru harus menerangkan kepada siswa, untuk dapat memecahkan masalah hubungan sosial yang aktual ada di masyarakat; (2) Guru harus dapat memilih masalah yang urgent sehingga menarik minat anak. Ia dapat menjelaskan dengan baik dan menarik, sehingga menarik minat anak; (3) Agar siswa memahami peristiwanya maka guru harus bisa menceritakan sambil mengatur adegan pertama ${ }^{7}$

\section{Pengertian dan Ruang Lingkup Bahasa Kedua}

Pemerolehan bahasa oleh anak-anak merupakan salah satu prestasi manusia yang paling hebat dan paling menakjubkan. Itulah sebabnya masalah ini mendapat perhatian besar. Pada saat itu telah dipelajari banyak hal mengenai bagaimana anak berbicara, mengerti, dan menggunakan bahasa, tetapi sangat sedikit sekali yang diketahui mengenai proses aktual perkembangan bahasa. Satu hal yang perlu diketahui bahwa pemerolehan bahasa sangat banyak ditentukan oleh interaksi rumit aspek-aspek kematangan biologis, kognitif, dan sosial.

Setiap pendekatan modern terhadap pemerolehan bahasa akan menghadapi kenyataan bahwa bahasa dibangun sejak semula oleh setiap anak, memanfaatkan aneka kapasitas bawaan sejak lahir yang beraneka ragam dalam interaksinya dengan pengalaman-pengalaman dunia dan sosial. Oleh karena itu, tidaklah mengherankan kalau kebanyakan pendekatan modern terhadap pemerolehan bahasa dititikberatkan pada salah satu aspek proses pemerolehan bahasa. Dimulai dari bahasa ibu atau bahasa pertama yang seorang anak dapatkan sejak lahir, sampai kepada bahasa kedua yang ingin dipelajari si anak setelah besar.

Bila dibahas secara singkat, Pemerolehan bahasa dalam istilah bahasa inggris disebut dengan Language Acquisition, yakni proses di mana penguasaan

${ }^{7}$ Ibid., 421.

Dirasah, Vol. 2, No. 2, Agustus 2019 
bahasa dilakukan oleh anak secara alami. Hal ini terjadi pada waktu dia belajar bahasa ibunya. Menurut Krashen, istilah pemerolehan, berbeda dengan pembelajaran (learning). Lebih jelasnya, pemerolehan bahasa memiliki definisi, yakni sebuah proses penguasaan dan pembangunan bahasa pertama, kedua, atau lainnya yang dilakukan oleh anak secara natural atau tidak disengaja. Pemerolehan bahasa sendiri, memiliki dua objek pembahasan utama. Pertama, pemerolehan bahasa pertama (bahasa Ibu) dan yang kedua, adalah pemerolehan bahasa kedua terjadi pada waktu dia belajar bahasa ibunya. ${ }^{8}$

Pemerolehan bahasa pertama adalah proses di mana anak mendapatkan bahasa ibunya, berlaku mulai masa kanak-kanak hingga masa puber atau akil baligh. Selanjutnya dalam pemerolehan bahasa pertama ini, terdapat teori yang sangat terkenal, dipopulerkan oleh seorang tokoh kebahasaan terkenal, Chomsky. Teori ini disebut dengan Hipotesis Nurani (Innateness Hypothesis), yang memiliki maksud bahwa setiap bayi manusia yang telah lahir sudah memiliki kapasitas khusus untuk berbahasa dan hal ini tidak dimiliki oleh makhlukmakhluk lain. ${ }^{9}$

Berbeda dengan Chomsky, Skinner berpendapat bahwa manusia terlahir di dunia tanpa dibekali apapun, bagaikan piring kosong, yang akan terisi oleh alam sekitar termasuk juga Bahasa. ${ }^{10}$ Lingkungan memiliki perang yang besar terhadap pembentukan karakter maupun skill setiap manusia. Apapun itu bentuknya, semua tidak akan lepas dari pengaruh lingkungan. Sebab seperti yang telah ditulis oleh Skinner di dalam bukunya "Velbal behavior", setiap gerakan dapat mempengaruhi organisme lain. "Any movement capable of affecting another organism". Teori yang populer ini sering disebut dengan behaviorisme. Skinner percaya bahwa seluruh makhluk memiliki kesamaan dalam proses belajar (termasuk belajar bahasa), beserta aksinya. ${ }^{11}$

Dari berbagai eksperimen yang telah dilakukannya, Skinner menyimpulkan bahwa pemerolehan pengetahuan, termasuk pengetahuan berbahasa, dipicu karena adanya stimulus yang dibarengi dengan respons. Bila

\footnotetext{
${ }^{8}$ Alif Cahya Setiyadi dan Mohammad Syam'un Salim, Pemerolehan Bahasa Kedua Menurut Stephen Krashen, (Jurnal At-Ta'dib: Fakultas Tarbiyah Institut Studi Islam Darussalam Gontor, 2013), 269.

${ }^{9}$ Ibid.

${ }^{10}$ Soenjono Dardjowirdjojo, Psikolingistik Pengantar Pemahaman Bahasa Manusia, edisi kedua, (Jakarta: Yayasan Obor Indonesia, 2005), 235.

${ }^{11}$ Alif Cahya, Pemerolehan Bahasa., 269.
}

Dirasah, Vol. 2, No. 2, Agustus 2019 
respons nya sesuai dengan yang diharapkan maka akan mendapat sebuah hadiah, bila sebaliknya maka akan mendapat sebuah hukuman. Dari proses pengulangan seperti inilah muncul kebiasaan. Menurutnya pula, bahasa adalah seperangkat kebiasaan, dan kebiasaan itu bisa tercapai dengan sempurna, bila telah melalui latihan berkali-kali dan berulang-ulang. Sebab Latihan (drill) merupakan bagian yang sangat penting dan tak terpisahkan dalam pengajaran bahasa asing, walaupun aplikasinya tertuju kepada metode-metode semisal Oral Approach atau Audiolingual Approach ataupun dengan metode-metode yang lainnya. ${ }^{12}$

Bahasa kedua adalah jenis bahasa yang bukan bahasa ibu (bahasa utama) bagi penutur, akan tetapi sering dipergunakan di lingkungan sekitar dari penutur sebagai media komunikasi lanjutan. Bahasa kedua berbeda dengan bahasa asing, sebab bahasa asing merupakan bahasa tambahan yang dipelajari penutur, namun tidak diterapkan di wilayah penutur tersebut. Beberapa bahasa kedua dipergunakan di berbagai negara sebagai bahasa formal (lingua franca). Bahasa Indonesia merupakan salah satu contoh bahasa kedua yang dipergunakan sebagai bahasa percakapan nasional dengan bahasa lokal daerah sebagai bahasa asli (native). ${ }^{13}$

Dalam masyarakat multilingual tentu akan ada pengajaran bahasa kedua (dan mungkin juga ketiga). Bahkan kedua ini bisa bahasa nasional, bahasa resmi kenegaraan, bahasa resmi kedaerahan atau juga bahasa asing ( bukan bahasa asli penduduk pribumi). Di Indonesia pada umumnya bahasa Indonesia adalah bahasa kedua yang berarti juga berstatus sebagai bahasa nasional dan bahasa resmi kenegaraan. Pengajaran bahasa kedua di Indonesia secara formal dimulai ketika anak memasuki pendidikan dasar (kira-kira berusia 6 tahun) untuk bahasa nasional. ${ }^{14}$

Dengan demikian dapat disimpulkan bahwa terdapat hubungan antara bermain peran dengan pembelajaran bahasa kedua yang menyenangkan, hal ini dapat dilihat dari tujuan penerapan bermain peran itu sendiri.

\footnotetext{
12 Ibid., 270.

13 Abdul Chaer dan Leonie Agustina, Sosiolinguistik: Perkenalan Awal (Jakarta: PT. Rineka Cipta, 2004), 214.

${ }^{14}$ Ibid, 215
} 


\section{Metode Penelitian}

Metode yang akan digunakan dalam penelitian ini adalah metode deskriptif. Nawawi menyatakan, Metode deskriptif adalah prosedur pemecahan masalah yang diselidiki dengan mengembangkan dan melukiskan keadaan subjek atau objek penelitian (seseorang, lembaga masyarakat, dan lain-lain), pada saat sekarang berdasarkan fakta-fakta yang tampak atau sebagaimana adanya. ${ }^{15}$

Nawawi menjelaskan ada tiga bentuk penelitian yaitu:

1. Survei (Survei studies) meliputi: Survei kelembagaan, analisis jabatan, analisis dokumen, analisis isi, survei pendapat umum, survei kemasyarakatan.

2. Studi hubungan (Interrelationship studies) meliputi: studi kasus, studi sebab akibat dan perbandingan, studi korelasi.

3. Studi perkembangan (Developmental studies) meliputi: Studi pertumbuhan, studi kecenderungan. ${ }^{16}$

Berdasarkan uraian tersebut, maka bentuk penelitian yang digunakan dalam penelitian ini adalah survei (survei studies). Jenis penelitian yang digunakan dalam penelitian ini adalah Penelitian Tindakan Kelas (Classroom Action Research).

Pendekatan penelitian yang digunakan dalam penelitian ini adalah penelitian kualitatif. Moleong mengatakan bahwa penelitian kualitatif adalah penelitian yang bermaksud untuk memahami fenomena tentang apa yang dialami oleh subyek penelitian, misalnya perilaku, persepsi, motivasi, tindakan dan lainlain. ${ }^{17}$ Subyek dalam penelitian ini adalah 1 orang guru kelas II A MI NU Miftahul Huda 02 Karangmalang, dan 18 siswa kelas II A MI NU Miftahul Huda 02 Karangmalang, yaitu terdiri dari laki-laki 9 orang dan perempuan 9 orang. Untuk memudahkan kegiatan penelitian, harus ditentukan indikator kinerja yang diperlukan untuk mengukur keberhasilan aspek yang akan ditingkatkan. Dalam landasan teori telah dijelaskan bahwa indikator pembelajaran yang enyenangkan terdiri dari menyenangkan secara fisik dan menyenangkan secara non fisik. Oleh karena itu indikator kinerjanya dapat di susun sebagai berikut:

\footnotetext{
${ }^{15}$ Hadari Nawawi, Metode Penelitian Bidang Sosial (Yogyakarta: Gajah Madja University Pres, 2007), 67.

${ }^{16}$ Ibid, 68.

${ }^{17}$ Lexy J. Moleong, Metodelogi Penuliasan Kualitatif (Bandung: Remaja Rosda Karya, 2007), 6.
}

Dirasah, Vol. 2, No. 2, Agustus 2019 


\section{Tabel 1. Indikator Kinerja} untuk Mengukur Pembelajaran yang Menyenangkan

\begin{tabular}{|c|c|c|c|c|}
\hline \multirow{2}{*}{ NO } & \multirow{2}{*}{ Indikator Kerja } & \multirow{2}{*}{ Base Line } & \multicolumn{2}{|c|}{ capaian } \\
\hline & & & Siklus I & Siklus II \\
\hline \multirow[t]{8}{*}{$\mathbf{A}$} & Menyenangkan secara & & & \\
\hline & fisik & & & \\
\hline & 1) Bergembira & $16,67 \%$ & & \\
\hline & 2) Senyum & $20 \%$ & & \\
\hline & $\begin{array}{l}\text { 3) Berani menunjuk tangan } \\
\text { saat bertanya }\end{array}$ & $10 \%$ & & \\
\hline & 4) Tertawa & $26,67 \%$ & & \\
\hline & 5) Tepuk Tangan & $26,67 \%$ & & \\
\hline & Rata-rata & $20,02 \%$ & & \\
\hline \multirow[t]{7}{*}{ B } & $\begin{array}{l}\text { Menyenangkan secara } \\
\text { non fisik }\end{array}$ & & & \\
\hline & 1) Perhatian tercurah & $16,67 \%$ & & \\
\hline & 2) Bersemangat & $16,67 \%$ & & \\
\hline & 3) Tertarik & $23,33 \%$ & & \\
\hline & $\begin{array}{l}\text { 4) Timbulnya minat dalam } \\
\text { pembelajaran }\end{array}$ & $16,67 \%$ & & \\
\hline & Rata-rata & $18,35 \%$ & & \\
\hline & Rata-rata $A+B: 2$ & $19,15 \%$ & & \\
\hline
\end{tabular}

Arikunto menyatakan bahwa secara garis besar terdapat empat tahapan yang lazim dilalui dalam Penelitian Tindakan Kelas, yaitu (1) Perencanaan, (2) Pelaksanaan, (3) Pengamatan, dan (4) Refleksi. Sesuai dengan bentuk pendekatan penelitian kualitatif dan sumber data yang akan digunakan, maka teknik pengumpulan data yang digunakan adalah teknik observasi langsung. ${ }^{18}$

Arikunto sebagai contoh dapat dikemukakan pengamatan yang dilakukan oleh peneliti untuk mengetahui proses belajar mengajar di kelas. Variabel akan terungkap di daftar, kemudian di tally kemunculannya, dan jika perlu kualitas kejadian itu dijabarkan lebih lanjut. ${ }^{19}$

Untuk menganalisis data berupa persentase dalam melaksanakan pembelajaran memahami peraturan perundang-undangan tingkat pusat dan

\footnotetext{
18 Suharsimi Arikunto, Prosedur Penelitian dan Suatu Pendekatan Praktik (Jakarta, Rineka Cipta, 2006), 16.

${ }^{19}$ Ibid, 229.
} 
daerah dengan menggunakan metode bermain peran digunakan perhitungan presentase menurut Sudijono (2008:43) rumus yang tepat adalah:

$\mathrm{P}=\frac{f}{N} \times 100 \%$

Dengan keterangan sebagai berikut: $\mathrm{P}=$ angka persentase $\mathrm{N}=$ jumlah frekuensi atau banyaknya individu $\mathrm{f}=$ frekuensi yang sedang dicari presentasenya. ${ }^{20}$

Untuk menentukan peningkatan pembelajaran yang menyenangkan dapat digunakan katagori peningkatan menurut Sudijono (2008:43) sebagai berikut:

1. $81 \%-100 \%$ sangat tinggi

2. $61 \%-80 \%$ tinggi

3. $41 \%-60 \%$ cukup tinggi

4. $21 \%-40 \%$ rendah

5. $0 \%-20 \%$ sangat rendah

\section{Hasil Penelitian dan Pembahasan}

Setelah melakukan observasi dan pengumpulan data pada proses Kegiatan Belajar Mengajar (KBM) di Kelas II A MI NU Miftahul Huda 02 Karangmalang pada hari Senin, 13 Nopember 2017 diperoleh data bahwa pembelajaran bahasa kedua pada mata pelajaran Bahasa Indonesia kelas II A MI NU Miftahul Huda 02 Karangmalang telah termuat dalam Rencana Pelaksanaan Pembelajaran (RPP) yang dipersiapkan guru yaitu dimasukkan pada tujuan pembelajaran yang ingin dicapai. Untuk mengimplementasikan pembelajaran di kelas, guru harus membuat RPP sebagaimana tercantum dalam Permendikbud No. 65 Tahun 2013.

Perencanaan pembelajaran meliputi penyusunan RPP dan penyiapan media dan sumber belajar, perangkat penilaian pembelajaran, dan skenario pembelajaran. Rencana pelaksanaan pembelajaran telah dibuat, skenario pembelajaran yakni apersepsi dan motivasi, kegiatan inti terdiri dari eksplorasi, elaborasi, dan konfirmasi, serta kegiatan penutup. Sumber belajar adalah buku Bina Bahasa Indonesia II A.

Berdasarkan observasi, persiapan untuk implementasi pembelajaran mata pelajaran Bahasa Indonesia telah dipersiapkan oleh guru dengan baik. Sebagai buktinya telah ada silabus, RPP, perangkat pembelajaran, dan skenario pembelajaran yang tercantum dalam RPP. Pelaksanaan pembelajaran merupakan

${ }^{20}$ Anas Sudijono, Pengantar Statistik Pendidikan (Jakarta: Raja Grapindo Persada, 2008),

Dirasah, Vol. 2, No. 2, Agustus 2019 
implementasi dari RPP. Pelaksanaan pembelajaran meliputi kegiatan pendahuluan, kegiatan inti, dan kegiatan penutup. Seluruh kegiatan ini telah tercantum dalam RPP yang disusun oleh guru. Dalam RPP, metode pembelajaran yang direncanakan adalah menggunakan metode bermain peran.

\section{Tabel 2. Rencana Pelaksanaan Pembelajaran}

Kegiatan awal, Metode yang digunakan guru dengan ceramah dan Tanya jawab. Guru Appersepsi dan mengajak peserta didik untuk merefresh pelajaran-pelajaran yang telah pembukaan diajarkan pada pertemuan sebelumnya.

Peserta didik diarahkan untuk dapat merespon pertanyaan-pertanyaan guru dengan menggunakan bahasa Indonesia yang baik dan benar. Misalnya guru bertanya " Siapakah teman kalian yang pagi ini tidak masuk sekolah?" peserta didik menjawab "yang mboten masuk sekolah Siti bu guru...". Kata mboten masuk kemudian diarahkan oleh guru dengan "tidak masuk".

\begin{tabular}{|c|c|}
\hline Kegiatan inti & $\begin{array}{l}\text { - Guru membagi peserta didik menjadi berpasang-pasangan, yang } \\
\text { satu berperan sebagai guru dan yang lainnya menjadi murid. Mereka } \\
\text { disuruh untuk berdialog sebebas-bebasnya menggunakan bahasa } \\
\text { Indonesia. Guru memantau "celoteh" peserta didik sambil sesekali } \\
\text { membetulkan kesalahan-kesalahan pengucapan kata dalam Bahasa } \\
\text { Indonesia. } \\
\text { Guru meminta beberapa murid untuk maju ke depan menceritakan } \\
\text { yang dirasakan ketika bermain peran menjadi guru dan murid, orang } \\
\text { tua dan anak, pedagang dan pembeli, dll. } \\
\text { Guru memberikan apresiasi kepada peserta didik yang bisa } \\
\text { menceritakan pengalamannya dalam bermain peran dengan } \\
\text { menggunakan bahasa yang baik. }\end{array}$ \\
\hline Penutup/Refleksi & $\begin{array}{l}\text { - } \quad \text { Guru bertanya kepada peserta didik apa yang mereka rasakan ketika } \\
\text { mereka sedang bermain peran } \\
\text { - } \quad \text { Guru menyimpulkan dan memberikan saran kepada siswa tentang } \\
\text { bagaimana berbahasa yang baik. } \\
\text { - } \quad \text { Guru memberikan motivasi kepada siswa agar selalu rajin belajar } \\
\text { dan tidak mudah putus asa. } \\
\text { - } \quad \text { Guru menutup pelajarang dg do'a bersama. }\end{array}$ \\
\hline
\end{tabular}

\section{Hasil Penelitian}

\section{Pelaksanaan penelitian awal}

Awal pelaksanaan penelitian, peneliti mempersiapan dan merencanakan penelitian awal (Base Line). Kemudian guru kolaborator melaksanakan proses pembelajaran seperti biasa. Bersamaan dengan proses pembelajaran yang 
dilakukan guru kolaborator, observer mengamati proses pembelajaran Bahasa Kedua menggunakan lembar observasi indikator pembelajaran. Pengamatan terhadap pembelajaran dilaksanakan oleh teman sejawat yaitu Sri Umiyati, dengan menggunakan lembar observasi yang telah disiapkan oleh peneliti. Sedangkan pengamatan terhadap langkah-langkah pembelajaran yang dilaksanakn guru diamati oleh peneliti. Hasil penelitian awal dapat dilihat Tabel 3 sebagai berikut.

\section{Tabel 3. Indikator Kinerja}

untuk Mengukur Pembelajaran yang Menyenangkan

\begin{tabular}{llcc}
\hline \multirow{2}{*}{ NO Indikator Kerja } & \multicolumn{2}{c}{ Base Line } \\
\cline { 3 - 4 } $\mathbf{A}$ & Menyenangkan secara fisik & Muncul & Tidak Muncul \\
\hline & 1) Bergembira & $16,67 \%$ & $83,33 \%$ \\
2) Senyum & $22,23 \%$ & $78,00 \%$ \\
3) Berani menunjuk tangan saat bertanya & $11,11 \%$ & $88,89 \%$ \\
4) Tertawa & $27,78 \%$ & $72,22 \%$ \\
5) Tepuk Tangan & $27,78 \%$ & $72,22 \%$ \\
Rata-rata & $\mathbf{2 1 , 1 1 \%}$ & $\mathbf{7 8 , 8 9 \%}$ \\
Menyenangkan secara non fisik & $16,67 \%$ & $83.33 \%$ \\
1) Perhatian tercurah & $16,67 \%$ & $83.33 \%$ \\
2) Bersemangat & $22,23 \%$ & $78,00 \%$ \\
3) Tertarik & $16,67 \%$ & $83.33 \%$ \\
4) Timbulnya minat dalam pembelajaran & $\mathbf{1 8 , 0 6 \%}$ & $\mathbf{8 1 . 9 4 \%}$ \\
Rata-rata & $\mathbf{1 9 , 5 9 \%}$ & $\mathbf{8 0 . 4 2 \%}$ \\
\hline
\end{tabular}

Refleksi Refleksi dilakukan setelah melakukan penelitian awal (base line). Dari data yang telah diperoleh selama penelitian awal (base line), selanjutnya diadakan kesepakatan antara peneliti, guru kolaborator, dan observer untuk menilai kelebihan dan kekurangan dari tindakan yang telah dilakukan pada penelitian awal (base line). Adapun kelebihan pada penelitian awal (base line) sebagai, yaitu guru menguasai materi pelajaran dan semua siswa hadir. Sedangkan kekurangan penelitian awal (base line) yaitu siswa tidak tertarik terhadap pembelajaran dan siswa merasa tertekan, bosan, dan jenuh terhadap pembelajaran.

Untuk memperbaiki kekurangan yang muncul pada penelitian awal (base line), maka peneliti dan guru kolaborator beserta observer sepakat untuk melaksanakan penelitian pembelajaran bahasa kedua yang menyenangkan dengan metode bermain peran pada siklus I. 


\section{Pelaksanaan Penelitian Siklus I}

Sebelum melaksanakan siklus 1, peneliti mempersiapkan pembelajaran yang akan dilaksanakan. Penerapan dan tindakan pembelajaran bahasa kedua yang menyenangkan dengan menggunakan metode bermain peran pada siswa kelas II A MI NU Miftahul Huda 02 Karangmalang dilaksanakan pada hari Selasa, 14 Nopember 2017 selama 70 menit yaitu pada pukul $07.00-08.10$ WIB, yang dihadiri oleh seluruh siswa sebanyak 18 orang. Pelaksanaan pembelajaran dilaksanakan oleh guru kolaborator sesuai dengan sharing antara peneliti dan guru kolaborator yang telah dilakukan sebelumnya.

Pengamatan terhadap pembelajaran dilaksanakan oleh teman sejawat yaitu Sri Umiyati, dengan menggunakan lembar observasi yang telah disiapkan oleh peneliti. Sedangkan pengamatan terhadap langkah-langkah pembelajaran yang dilaksanakan guru diamati oleh peneliti. Hasil observasi siklus I dapat dilihat pada tabel 3 sebagai berikut:

\section{Tabel 4. Hasil Penelitian Pembelajaran}

Pendidikan Bahasa Kedua yang Menyenangkan dengan Menggunakan Metode Bermain Peran Siklus I

\begin{tabular}{|c|c|c|c|c|c|}
\hline \multirow{3}{*}{ NO } & \multirow{2}{*}{ Indikator Kerja } & \multicolumn{4}{|c|}{ Base Line } \\
\hline & & \multicolumn{2}{|c|}{ Muncul } & \multicolumn{2}{|c|}{ Tidak Muncul } \\
\hline & & Jumlah & $\%$ & Jumlah & $\%$ \\
\hline \multirow[t]{7}{*}{$\mathbf{A}$} & Menyenangkan secara fisik & & & & \\
\hline & 1) Bergembira & 12 & $66,67 \%$ & 16 & $33,33 \%$ \\
\hline & 2) Senyum & 14 & $77,78 \%$ & 4 & $22,22 \%$ \\
\hline & $\begin{array}{l}\text { 3) Berani menunjuk tangan saat } \\
\text { bertanya }\end{array}$ & 13 & $72,22 \%$ & 5 & $27,78 \%$ \\
\hline & 4) Tertawa & 16 & $88,89 \%$ & 3 & $11,11 \%$ \\
\hline & 5) Tepuk Tangan & 10 & $55,56 \%$ & 8 & $44,44 \%$ \\
\hline & Rata-rata & & $72,22 \%$ & & $27,78 \%$ \\
\hline \multirow[t]{7}{*}{$\mathbf{B}$} & Menyenangkan secara non fisik & & & & \\
\hline & 1) Perhatian tercurah & 11 & $61,11 \%$ & 7 & $38,89 \%$ \\
\hline & 2) Bersemangat & 11 & $61,11 \%$ & 7 & $38,89 \%$ \\
\hline & 3) Tertarik & 10 & $55,56 \%$ & 8 & $44,44 \%$ \\
\hline & $\begin{array}{l}\text { 4) Timbulnya minat dalam } \\
\text { pembelajaran }\end{array}$ & 13 & $72,22 \%$ & 5 & $27,78 \%$ \\
\hline & Rata-rata & & $62.5 \%$ & & $\mathbf{3 7 , 5 \%}$ \\
\hline & Rata-rata $A+B: 2$ & & $67,36 \%$ & & $32,64 \%$ \\
\hline
\end{tabular}


Refleksi dilakukan setelah melakukan tindakan pada siklus I. Dari data yang telah diperoleh selama observasi siklus I, selanjutnya diadakan kesepakatan antara peneliti, guru kolaborator, dan observer untuk menilai kelebihan dan kekurangan dari tindakan yang telah dilakukan pada siklus I. Adapun kelebihan pada siklus I, yaitu terjadi peningkatan yang signifikan dari persentase base line terhadap hasil siklus I, guru menguasai materi pelajaran, siswa mulai tertarik pembelajaran dengan metode bermain peran, semua siswa hadir sehingga memudahkan dalam pengaturan kelompok seperti yang sudah direncanakan. Kekurangan siklus I guru masih kerepotan dalam membimbing siswa untuk bermain peran. Untuk memperbaiki kekurangan yang muncul pada siklus I, maka peneliti dan guru kolaborator beserta observer sepakat untuk melaksanakan tindakan kedua pada siklus II.

\section{Pelaksanaan Penelitian Siklus II}

Sebelum melaksanakan siklus 2, peneliti mempersiapkan pembelajaran yang akan dilaksanakan Penerapan dan tindakan pembelajaran bahasa kedua yang menyenangkan dengan menggunakan metode bermain peran pada siswa kelas II A MI NU Miftahul Huda 02 Karangmalang dilaksanakan pada hari Kamis, 23 Nopember 2017 selama 70 menit yaitu pukul 07.00 - 08.10 WIB, yang dihadiri oleh seluruh siswa sebanyak 18 orang. Pelaksanaan pembelajaran dilaksanakan oleh guru kolaborator sesuai dengan sharing antara peneliti dan guru kolaborator yang telah dilakukan sebelumnya. Pelaksanaan yang dilaksanakan oleh guru kolaborator lebih di titik beratkan pada kekurangan yang terjadi pada siklus I.

Pengamatan terhadap pembelajaran dilaksanakan oleh teman sejawat yaitu Sri Umiyati, dengan menggunakan lembar observasi yang telah disiapkan oleh peneliti. Sedangkan pengamatan terhadap langkah-langkah pembelajaran yang dilaksanakan guru diamati oleh peneliti. Hasil observasi siklus II dapat dilihat pada tabel 4 sebagai berikut:

Dirasah, Vol. 2, No. 2, Agustus 2019 
Tabel 3. Hasil Penelitian

Pembelajaran Bahasa Kedua yang Menyenangkan dengan Menggunakan Metode Bermain Peran Siklus II

\begin{tabular}{|c|c|c|c|c|c|}
\hline \multirow{3}{*}{$\begin{array}{l}\mathbf{N} \\
\mathbf{O}\end{array}$} & \multirow{3}{*}{ Indikator Kerja } & \multicolumn{4}{|c|}{ Base Line } \\
\hline & & \multicolumn{2}{|c|}{ Muncul } & \multicolumn{2}{|c|}{ Tidak Muncul } \\
\hline & & Jumlah & $\%$ & $\begin{array}{l}\text { Jum } \\
\text { lah }\end{array}$ & $\%$ \\
\hline \multirow[t]{7}{*}{$\mathbf{A}$} & Menyenangkan secara fisik & & & & \\
\hline & 1) Bergembira & 14 & $77,78 \%$ & 4 & $22,22 \%$ \\
\hline & 2) Senyum & 15 & $83,33 \%$ & 3 & $16,67 \%$ \\
\hline & $\begin{array}{l}\text { 3) Berani menunjuk tangan saat } \\
\text { bertanya }\end{array}$ & 14 & $77,78 \%$ & 4 & $22,22 \%$ \\
\hline & 4) Tertawa & 16 & $88,89 \%$ & 2 & $11,11 \%$ \\
\hline & 5) Tepuk Tangan & 12 & $66,67 \%$ & 6 & $33.33 \%$ \\
\hline & Rata-rata & & $\mathbf{7 8 , 8 9 \%}$ & & $21,11 \%$ \\
\hline \multirow[t]{7}{*}{ B } & Menyenangkan secara non fisik & & & & \\
\hline & 1) Perhatian tercurah & 13 & $72,22 \%$ & 5 & $27,78 \%$ \\
\hline & 2) Bersemangat & 14 & $77,78 \%$ & 4 & $22,22 \%$ \\
\hline & 3) Tertarik & 12 & $66,67 \%$ & 6 & $33.33 \%$ \\
\hline & $\begin{array}{l}\text { 4) Timbulnya minat dalam } \\
\text { pembelajaran }\end{array}$ & 15 & $83,33 \%$ & 3 & $16,67 \%$ \\
\hline & Rata-rata & & $75 \%$ & & $25 \%$ \\
\hline & Rata-rata $A+B: 2$ & & $76,95 \%$ & & $23,05 \%$ \\
\hline
\end{tabular}

Refleksi dilakukan setelah melakukan tindakan pada siklus II. Dari data yang telah diperoleh selama observasi siklus II, selanjutnya diadakan kesepakatan antara peneliti, guru kolaborator, dan observer untuk menilai kelebihan dan kekurangan dari tindakan yang telah dilakukan pada siklus II. Adapun kelebihan pada siklus II, yaitu terjadi peningkatan pada pembelajaran, guru menguasai materi pelajaran dan sudah terampil menggunakan metode bermain peran, siswa sudah terbiasa dengan metode bermain peran, yang sebelumnya sudah diterapkan pada siklus I sehingga memudahkan mereka dalam mengambil posisi untuk bermain peran sehingga tidak memerlukan banyak waktu, semua siswa hadir sehingga memudahkan dalam pengaturan kelompok seperti yang sudah direncanakan.

Kekurangan Siklus II, yaitu guru memulai pembelajaran lebih lama dari jadwal yang sudah disepakati, akibatnya pembelajaran tidak sesuai dengan alokasi waktu, masih ada beberapa orang siswa yang kurang aktif pada saat pembelajaran. Tetapi dengan frekuensi yang sedikit, tidak total $100 \%$ siswa keseluruhan aktif. Setelah melakukan siklus II ternyata terjadi peningkatan yang 
signifikan, walaupun peningkatannya tidak keseluruhan (100\%) tetapi sudah dianggap sampai titik jenuh, yaitu tidak terjadi peningkatan lagi. Sehingga penelitian dilakukan hanya sampai pada siklus II.

\section{Rekapitulasi Hasil Penelitian Awal (Base Line), Siklus I dan Siklus II}

Setelah melakukan penelitian awal (base line) dan 2 siklus penelitian pada pembelajaran bahasa kedua yang Menyenangkan dengan menggunakan metode mermain meran pada Siswa II A yang dilakukan oleh peneliti berkolaborasi dengan Ibu Sri Umiyati, S.Pd.I diperoleh rekapitulasi pembelajaran yang menyenangkan yang dapat dilihat pada Tabel 6 sebagai berikut:

Tabel 4. Rekapitulasi Penelitian

Pembelajaran Bahasa Kedua yang Menyenangkan

dengan Metode Bermain Peran

\begin{tabular}{|c|c|c|c|c|c|c|}
\hline \multirow[t]{2}{*}{ NO } & \multirow[t]{2}{*}{ Indikator Kerja } & \multirow{2}{*}{$\begin{array}{l}\text { Base } \\
\text { Line }\end{array}$} & \multicolumn{2}{|c|}{ Siklus I } & \multicolumn{2}{|c|}{ Siklus II } \\
\hline & & & Muncul & $\begin{array}{c}\text { Tidak } \\
\text { muncul }\end{array}$ & Muncul & $\begin{array}{r}\text { Tidak } \\
\text { muncul }\end{array}$ \\
\hline \multirow[t]{7}{*}{$\mathbf{A}$} & $\begin{array}{l}\text { Menyenangkan secara } \\
\text { fisik }\end{array}$ & & & & & \\
\hline & 1) Bergembira & $16,67 \%$ & $66,67 \%$ & $33,33 \%$ & $77,78 \%$ & $22,22 \%$ \\
\hline & 2) Senyum & $22,23 \%$ & $77,78 \%$ & $22,22 \%$ & $83,33 \%$ & $16,67 \%$ \\
\hline & $\begin{array}{l}\text { 3) Berani menunjuk tangan } \\
\text { saat bertanya }\end{array}$ & $11,11 \%$ & $72,22 \%$ & $27,78 \%$ & $77,78 \%$ & $22,22 \%$ \\
\hline & 4) Tertawa & $27,78 \%$ & $88,89 \%$ & $11,11 \%$ & $88,89 \%$ & $11,11 \%$ \\
\hline & 5) Tepuk Tangan & $27,78 \%$ & $55,56 \%$ & $44,44 \%$ & $66,67 \%$ & $33.33 \%$ \\
\hline & Rata-rata & $21,11 \%$ & $72,22 \%$ & $\mathbf{2 7 , 7 8 \%}$ & $\mathbf{7 8 , 8 9 \%}$ & $21,11 \%$ \\
\hline \multirow[t]{7}{*}{$\mathbf{B}$} & $\begin{array}{l}\text { Menyenangkan secara } \\
\text { non fisik }\end{array}$ & & & & & \\
\hline & 1) Perhatian tercurah & $16,67 \%$ & $61,11 \%$ & $38,89 \%$ & $72,22 \%$ & $27,78 \%$ \\
\hline & 2) Bersemangat & $16,67 \%$ & $61,11 \%$ & $38,89 \%$ & $77,78 \%$ & $22,22 \%$ \\
\hline & 3) Tertarik & $22,23 \%$ & $55,56 \%$ & $44,44 \%$ & $66,67 \%$ & $33.33 \%$ \\
\hline & $\begin{array}{l}\text { 4) Timbulnya minat dalam } \\
\text { pembelajaran }\end{array}$ & $16,67 \%$ & $72,22 \%$ & $27,78 \%$ & $83,33 \%$ & $16,67 \%$ \\
\hline & Rata-rata & $18,06 \%$ & $62.5 \%$ & $37,5 \%$ & $75 \%$ & $25 \%$ \\
\hline & Rata-rata $A+B: 2$ & $19,59 \%$ & $67,36 \%$ & $32,64 \%$ & $76,95 \%$ & $23,05 \%$ \\
\hline
\end{tabular}

Berdasarkan tabel 4 dapat dilihat peningkatan yang terjadi pada setiap indikator kinerja pembelajaran siswa yang menyenangkan dengan menggunakan metode bermain peran. 


\section{Pembahasan}

Berdasarkan rekapitulasi pembelajaran bahasa kedua yang menyenangkan dengan menggunakan metode bermain peran pada siswa kelas II A MI NU Miftahul Huda 02 Karangmalang dapat dilihat peningkatan pembelajaran pada setiap indikator kinerja sebagai berikut:

a. Menyenangkan secara fisik pada base line $21,11 \%$ meningkat menjadi $72,22 \%$ pada siklus I dengan selisih sebesar 51,11\% dan dikatagorikan "cukup tinggi". Menyenangkan secara fisik pada base line 21,11\% meningkat menjadi 78,89\% pada siklus II dengan selisih sebesar $57,78 \%$ dan dikatagorikan "cukup tinggi". Berdasarkan selisih indikator pembelajaran yang menyenangkan secara fisik pada base line ke siklus II sebesar 57,78\%, kenaikan menyenangkan secara fisik dikatagorikan "Cukup Tinggi".

b. Menyenangkan secara non fisik pada base line $18,06 \%$ meningkat menjadi $67,36 \%$ pada siklus I dengan selisih sebesar $49,3 \%$ dan dikatagorikan "cukup tinggi". Menyenangkan secara non fisik pada base line 18,06\% meningkat menjadi $76,95 \%$ pada siklus II dengan selisih sebesar $58,89 \%$ dan dikatagorikan "cukup tinggi".

c. Berdasarkan selisih indikator pembelajaran yang menyenangkan secara non fisik pada base line ke siklus II sebesar 58,89\%, kenaikan menyenangkan secara non fisik dikatagorikan "Cukup Tinggi".

\section{Penutup}

Berdasarkan hasil penelitian yang diperoleh melalui penelitian terhadap peningkatan Pembelajaran Bahasa Kedua yang menyenangkan dengan menggunakan metode bermain peran pada siswa kelas II A MI NU Miftahul Huda 02 Karangmalang mengalami peningkatan dari base line sebesar 19,59\% ke siklus II menjadi 76,95\% meningkat sebesar 57,36\% dengan dikatagorikan "Cukup Tinggi". Rekomendasi yang diajukan, yaitu proses pembelajaran yang dirancang guru harus dapat melibatkan siswa secara aktif, bukan hanya secara fisik tetapi juga secara non fisik. Selain itu, rendahnya keaktifan siswa dapat berdampak terhadap hasil belajar siswa. Sehingga guru tidak selalu menyalahkan siswa yang tidak aktif atau malas-malasan ketika proses pembelajaran berlangsung tetapi guru harus menilai kinerjanya sendiri terlebih dahulu. Selain itu, keaktifan siswa sangat diperlukan dalam proses pembelajaran Bahasa Kedua. Oleh karena itu, hendaknya guru dapat mengaktifkan siswa dengan menggunakan pembelajaran yang menyenangkan dalam proses pembelajaran 
bahasa kedua terutama metode bermain peran agar pembelajaran lebih bermakna dan menyenangkan siswa sehingga siswa dapat berpartisipasi langsung dalam proses pembelajaran.

\section{Daftar Pustaka}

Arikunto, Suharsimi. Prosedur Penelitian dan Suatu Pendekatan Praktik. Jakarta: Rineka Cipta. 2006.

Chaer, Abdul dan Agustina, Leonie. Sosiolinguistik (Perkenalan Awal). Jakarta: PT. Rineka Cipta. 2004.

Dardjowirdjojo, Soenjono. Psikolingistik Pengantar Pemahaman Bahasa Manusia. Jakarta: Yayasan Obor Indonesia. 2005.

Diane, Novita. Mengajar Lewat Permainan. Jakarta: PT Gramedia Widiasarana Indonesia. 2005.

Indrawati dan Setiawan, Wawan. Pembelajaran Aktif, Kreatif, Efektif dan Menyenangkan, Untuk Guru SD. Jakarta: PPPPTK IPA. 2009.

Komara, Endang. Model Bermain Peran dalam Pembelajaran Partisipatif. FKIP UNTAN Pontianak. 2009.

Meir, Dave. The Accelerated Learning Handbook. Terjemahan oleh Rahmani Astuti. Bandung: Kaifa. 2002.

Moleong, J. Lexy. Metodelogi Penuliasan Kualitatif. Bandung: Remaja Rosda Karya. 2007.

Nawawi, Hadari. Metode Penelitian Bidang Sosial. Yogyakarta: Gajah Madja University Pres. 2007.

Peraturan Menteri Pendidikan dan Kebudayaan Republik Indonesia No. 65 Tahun 2013

Setiyadi, Alif Cahya dan Salim, Mohammad Syam'un. Pemerolehan Bahasa Kedua Menurut Stephen Krashen, Jurnal At-Ta'dib. Vol. 2 No.3 Tahun 2013.

Dirasah, Vol. 2, No. 2, Agustus 2019 
Sudijono, Anas. Pengantar Statistik Pendidikan. Jakarta: Raja Grafindo Persada. 2008.

Suharto. "Peningkatan Motivasi Belajar IPA Pada Kompetensi Dasar Tata Surya Dengan Metode Pembelajaran Bermain Peran (Role Palying)." Jurnal Dinamika. No. 3, Vol. 3. 2013.

Sumardi, Kamin. Pembelajaran Dengan Pendekatan Pakem. Cirebon: Disampaikan Dalam Seminar Nasional Creating Engaging Lesson. 2010.

Trianto. Model Pembelajaran Terpadu dalam Teori dan Praktek. Jakarta: Prestasi Pustaka Publisher. 2007.

Copyright (C) 2019 Journal Dirasah: Vol. 2, No. 2, Agustus 2019, p-ISSN: 2615-0212, e-ISSN; 2621-2838

Copyright rests with the authors

Copyright of Jurnal Dirasah is the property of Jurnal Dirasah and its content may not be copied or emailed to multiple sites or posted to a listserv without the copyright holder's express written permission. However, users may print, download, or email articles for individual use.

https://ejournal.iaifa.ac.id/index.php/dirasah 